\title{
Surdocardiac syndrome of Jervell and Lange-Nielsen, with prolonged QT interval present at birth, and severe anaemia and syncopal attacks in childhood
}

\author{
Asbjørn Langslet and Svein Jan Sørland \\ From The Department of Paediatric Cardiology, Rikshospitalet, Oslo, Norway
}

A case of the surdocardiac syndrome of fervell and Lange-Nielsen, with prolonged QT interval in the electrocardiogram at birth, is described. The affected girl presented $3 \frac{1}{2}$ years later with severe iron deficiency anaemia, despite apparently adequate nutrition. At the age of $4 \frac{1}{2}$ years she had a sudden attack of unconsciousness. Treatment with the beta-adrenoceptor blocker practolol was started and 3 years after initiation of this treatment she has been free from syncopal attacks. The QT interval remains prolonged. Her brother also had severe iron deficiency anaemia and had several attacks of unconsciousness before he died suddenly at the age of $3 \frac{1}{2}$ years.

Since Jervell and Lange-Nielsen described the surdocardiac syndrome in 1957, reports of about 40 cases have been published (see Jervell, I97 ; Pernot, 1972), though some of these may be doubtful examples of the syndrome (Furlanello, Macca, and Dal Palù, I972; Mathews, Blount, and Townsend, 1972).

While the syndrome is thought to be an inherited congenital disorder (see Jervell, 197I), no reports of electrocardiographic abnormalities at birth appear to have been published. The present paper describes an affected girl found to have a prolonged QT interval almost immediately after birth.

Hypochromic anaemia has been observed in many patients with the syndrome (Fraser, Froggatt, and James, 1964a; Jervell and Sivertssen, 1967; Pernot, 1972). The anaemia has been moderate in all the patients previously reported. The above patient and an affected sib both had severe hypochromic anaemia whilst eating a normal Norwegian diet.

\section{Case reports}

\section{Case I}

This girl was the first child of healthy non-consanguineous parents; during labour the foetal heart rhythm was irregular. An electrocardiogram 2 hours after birth revealed a long QT interval, of $0.52 \mathrm{~s}$ (Fig. I) with a heart rate of $95 /$ minute. In a normal newborn girl the

Received 22 November 1974 . expected QT interval for the same heart rate is $0.30 \pm$ $0.02 \mathrm{~s}$ (standard error) estimated according to Alimurung et al. (1950) and $0.31 \pm 0.04 \mathrm{~s}$, according to the formula of Fraser, Froggatt, and Murphy (1964b).

When the child was $I \frac{1}{2}$ years old, bilateral neurogenic deafness was diagnosed, and at $3 \frac{1}{2}$ years of age she was admitted to our hospital because of anaemia.

At that time haemoglobin was $3.9 \mathrm{~g} / \mathrm{dl}$, serum iron $4.48 \mu \mathrm{mol} / 1(25 \mu \mathrm{g} / \mathrm{dl})$ and total iron binding capacity $8 \mathrm{r} .45 \mu \mathrm{mol} / \mathrm{l}(455 \mu \mathrm{g} / \mathrm{dl})$.

The anaemia was hypochromic, microcytic, and other laboratory findings were also consistent with iron deficiency anaemia. No obvious nutritional or other explanations for the iron deficiency could be found. Iron-enriched cereals had been given throughout the first year of life.

Treatment with oral iron was now started. In the second week of treatment there was considerable reticulocytosis; after 3 weeks haemoglobin was $5.6 \mathrm{~g} / \mathrm{dl}$, and after 6 weeks $6.2 \mathrm{~g} / \mathrm{dl}$. The iron medication was continued and when the patient was re-examined after I year, haemoglobin was $9.2 \mathrm{~g} / \mathrm{dl}$, serum iron $4.48 \mu \mathrm{mol} / 1$ $(25 \mu \mathrm{g} / \mathrm{dl})$, and total iron binding capacity $68.92 \mu \mathrm{mol} / 1$ $(385 \mu \mathrm{g} / \mathrm{dl})$. After 2 years, haemoglobin was $11 \mathrm{~g} / \mathrm{dl}$, serum iron $10.74 \mu \mathrm{mol} / 1(60 \mu \mathrm{g} / \mathrm{dl})$, and total iron binding capacity $62.65 \mu \mathrm{mol} / 1(350 \mu \mathrm{g} / \mathrm{dl})$.

An electrocardiogram, when she was $3 \frac{1}{2}$ years old, showed a prolonged QT interval of $0.52-0.62 \mathrm{~s}$ (Fig. 2) and abnormal, alternating TU waves. The heart rate was $72 / \mathrm{min}$. The expected QT interval in normal girls of the same age and heart rate is $0.35 \pm 0.02 \mathrm{~s}$, according to Alimurung et al. (1950) and $0.35 \pm 0.04 \mathrm{~s}$ according to Fraser et al. (1964b).

She had not had syncopal attacks at that time. When 

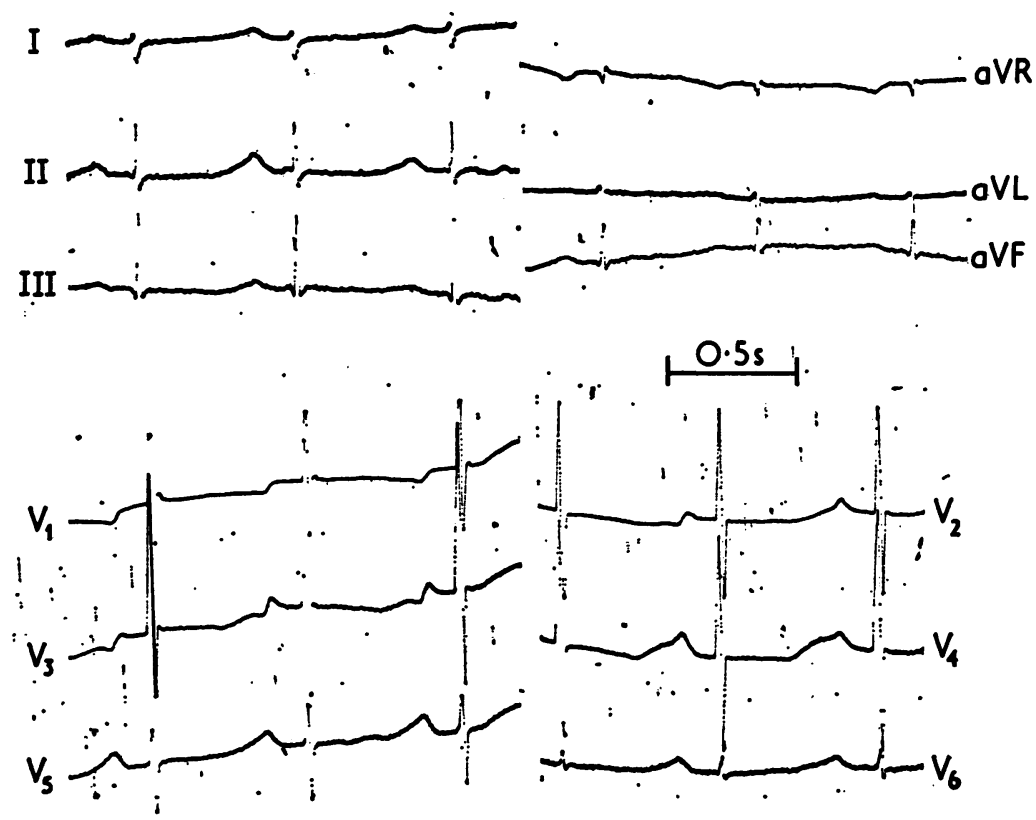

FIG. I Case I. Electrocardiogram 2 hours after birth, showing a prolonged $Q T$ interval of 0.52 s. Paper speed $50 \mathrm{~mm}$ per s.
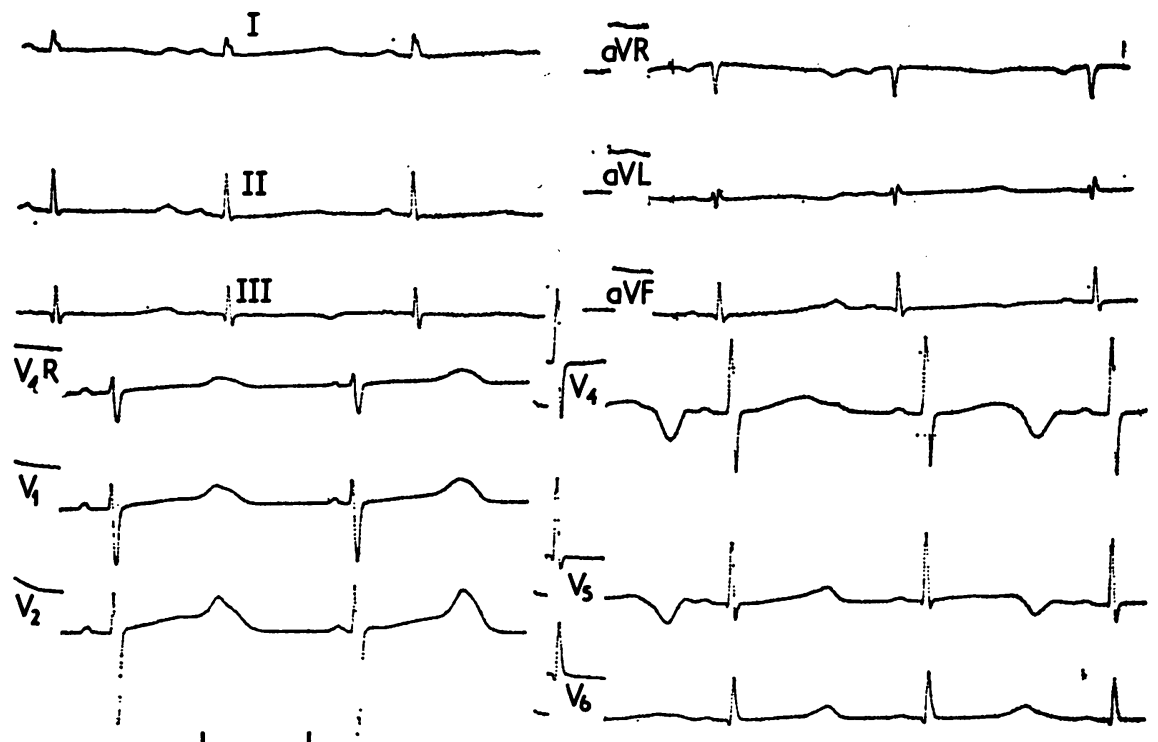

$0.5 \mathrm{~s}$

FIG. 2 Case I. Electrocardiogram at the age of $3 \frac{1}{2}$ years, showing a prolonged $Q T$ interval of 0.52 to $0.62 \mathrm{~s}$, and abnormal alternating $T U$ waves. Paper speed $50 \mathrm{~mm}$ per s. 
she was $4 \frac{1}{2}$ years old, however, she had a sudden attack of unconsciousness and was readmitted to our hospital. The electrocardiogram was unchanged, with a long QT interval and abnormal TU waves typical of the surdocardiac syndrome. Treatment with the beta-adrenoceptor blocker propranolol was started. The QT interval was hardly altered $(0.55$ to $0.66 \mathrm{~s})$, but the heart rate fell from 65 to 57 per minute. We, therefore, changed to practolol. The heart rate rose to 65 and the QT interval was $0.62 \mathrm{~s}$. At present, 3 years later, she has been free from syncopal attacks.

\section{Case 2}

This boy was the brother of Case I and the parents' second child: during labour the foetal heart rate was slow and the rhythm irregular. He was in good condition in the neonatal period and electrocardiograph tracings were not made. In his first year of life bilateral neurogenic deafness was diagnosed. When the boy was $2 \frac{1}{2}$ years old he was examined as an outpatient at our hospital because of anaemia. The haemoglobin was $7.5 \mathrm{~g} / \mathrm{dl}$, serum iron $6.27 \mu \mathrm{mol} / 1$ (35 $\mu \mathrm{g} / \mathrm{dl})$, and total iron binding capacity $65.34 \mu \mathrm{mol} / 1$ (365 $\mu \mathrm{g} / \mathrm{dl})$. The anaemia was classified as an iron deficiency anaemia.

No dietary deficiencies could be found. Iron-enriched cereals had been given throughout the first year of life. Treatment with iron was begun, but unfortunately the patient was not seen again at our hospital. At the age of $2 \frac{3}{4}$ years he had his first attack of unconsciousness and convulsions, and during the following year he had several similar attacks, with and without convulsions. Repeated neurological examinations including electroencephalograms did not reveal any pathological findings, but the disorder was probably misinterpreted as epilepsy and the boy was treated with phenobarbitone and diphenylhydantoin. This therapy had no effect on the attacks. When he was $3 \frac{1}{2}$ years old he died suddenly. Electrocardiograms had never been taken. A necropsy was performed but there were no abnormal findings.

\section{Discussion}

In most of the cases with the surdocardiac syndrome previously published, the first syncopal attack occurred between the ages 2 and 6 years (Jervell, 197I).

Only 4 children had the first attack in their first year of life (see Jervell, 1971; Pernot, 1972). The youngest was $2 \frac{1}{2}$ months when the first attack occurred (Jervell, Thingstad, and Endsjö, 1966). The syndrome is thought to be an inherited congenital disorder (see Jervell, 1971) and the typical electrocardiographic pattern probably to be already present at birth, as was found in the case of the affected girl in this report who presented with a prolonged QT interval in the electrocardiographic tracings made just after delivery.

The diagnosis, however, is seldom made at this early age. There is no obvious reason why the syncopal attacks usually start after the age of 2 years. Perhaps the physical and mental stresses that often provoke the attacks increase after that age. It is interesting that both children in the present report had an irregular heart rhythm during delivery.

It is reasonable to imagine that the electrocardiographic abnormality is present also in the foetal electrocardiogram in affected individuals, which raises the possibility of prenatal diagnosis in suspected cases.

Fraser and co-workers (1964a) suggested that hypochromic anaemia may be an additional feature of the surdocardiac syndrome. This view is supported by the severe iron deficiency anaemia observed in our patients, despite apparently adequate nutrition. A cell membrane dysfunction with impeded transport of ions involved in membrane repolarization as well as iron, may perhaps be responsible for the abnormalities in the electrocardiogram and cardiac rhythm, the deafness, and the predisposition to iron deficiency.

\section{References}

Alimurung, M. A., Joseph, L. G., Craige, E., and Massell, B. F. (1950). The Q-T interval in normal infants and children. Circulation, I, 1329.

Fraser, G. R., Froggatt, P., and James, T. N. (1964a). Congenital deafness associated with electrocardiographic abnormalities, fainting attacks and sudden death. Quarterly Fournal of Medicine, 33, 36r.

Fraser, G. R., Froggatt, P., and Murphy, T. (1964b). Genetical aspects of the cardio-auditory syndrome of Jervell and Lange-Nielsen (congenital deafness and electrocardiographic abnormalities). Annals of Human Genetics, 28, 133.

Furlanello, F., Maccà, F., and Dal Palù, C. (1972). Observation on a case of Jervell and Lange-Nielsen syndrome in an adult. British Heart fournal, 34, 648.

Jervell, A. (197I). Surdocardiac and related syndromes in children. Advances in Internal Medicine, 17, 425.

Jervell, A., and Lange-Nielsen, F. (1957). Congenital deafmutism, functional heart disease with prolongation of the QT interval, and sudden death. American Heart fournal, $54,59$.

Jervell, A., and Sivertssen, E. (1967). Surdo-cardialt syndrom. Nordisk Medicin, 78, 1443.

Jervell, A., Thingstad, R., and Endsjö, T. O. (1966). The surdo-cardiac syndrome. American Heart fournal, 72, 582.

Mathews, E. C., Blount, A. W., and Townsend, J. I. (I972). Q-T prolongation and ventricular arrhythmias, with and without deafness, in the same family. American fournal of Cardiology, 29, 702.

Pernot, C. (1972). Le syndrome cardio-auditif de Jervell et Lange-Nielsen. Aspects electrocardiographiques. Proceedings of the Association of European Pediatric Cardiologists, 8, 28.

Requests for reprints to Dr. Svein Jan Sørland, Department of Paediatric Cardiology, Rikshospitalet, Oslo I, Norway. 